\title{
From the outside in: bringing student engagement to the centre
}

DOI:

10.1080/13614533.2020.1777172

\section{Document Version}

Accepted author manuscript

Link to publication record in Manchester Research Explorer

\section{Citation for published version (APA):}

Blake, J., Aston, S., \& Grayson, N. (2020). From the outside in: bringing student engagement to the centre. New Review of Academic Librarianship, 1-10. https://doi.org/10.1080/13614533.2020.1777172

\section{Published in:}

New Review of Academic Librarianship

\section{Citing this paper}

Please note that where the full-text provided on Manchester Research Explorer is the Author Accepted Manuscript or Proof version this may differ from the final Published version. If citing, it is advised that you check and use the publisher's definitive version.

\section{General rights}

Copyright and moral rights for the publications made accessible in the Research Explorer are retained by the authors and/or other copyright owners and it is a condition of accessing publications that users recognise and abide by the legal requirements associated with these rights.

\section{Takedown policy}

If you believe that this document breaches copyright please refer to the University of Manchester's Takedown Procedures [http://man.ac.uk/04Y6Bo] or contact uml.scholarlycommunications@manchester.ac.uk providing relevant details, so we can investigate your claim.

\section{OPEN ACCESS}


Jennifer RS Blake*, Sam Aston, and Dr Nicola Grayson

University of Manchester Library, University of Manchester, Manchester, UK

University of Manchester Library, University of Manchester, Oxford Road, M13 9PP, jennie.blake@manchester.ac.uk 


\section{From the outside in: bringing student engagement to the centre}

This case study looks at the University of Manchester Library Student Team (UMLST) as a model for inclusive community engagement. It examines the impact of working with students as co-creators and explores how the ideas, insights and value they bring serve to drive change in a way that enables the Library to deliver in relation to current student needs, rather than react to past requirements. It discusses how the UMLST have engaged in and delivered peerled support, how they have shaped space and policies and how this model places the Library within the community, instead of framing the community as an outside group or other with which to engage.

Keywords: student engagement; University libraries, collaboration, library staff development, students

\section{Introduction}

The tension between delivering professional, expert-led services and incorporating the student voice is one that is deeply familiar to academic libraries (Murphy, 2017). Libraries are dynamic and innovative places that deliver a wide range of support and services to students, academics and the larger community within and outside of higher education. Some of the most powerful learning comes when students are placed at the centre of the development process, allowing them to feel real investment in the Library and its services and creating an integrated learning community (Cook-Sather and Felten, 2017). This requires that libraries and those working there seek to see their work, such as teaching, from the student perspective (Ramsden, 2002). The inclusion of students' voices and actions within the wider work of universities has prompted institutions to ask students what they think about services, what they would like to see changed and their visions for the institutions (National Union of Students, 2014; AdvanceHE, 2019). In this paper, we use a case study from our institution to discuss how to extend engagement and encourage students to move from a collaborative "bridge" to the 
community to a central part of practice and service. We believe that student engagement must mean more to academic libraries than student contact; it must become a broader term and more inclusive way of working, one that inspires future initiatives as well as allowing reflection on current practice.

Engagement has been a term with a myriad of definitions, even within libraries (Schlak, 2018). This case study demonstrates how the University of Manchester Library Student Team (UMLST) moved from a link to the student body to an integral part of the Library itself. We examine the UMLST's work as co-creators and developers of the resources and teaching for the My Learning Essentials programme and the changes prompted by other Library staff needing to examine their own assumptions and practices. Each of these aspects will highlight the move from bridge (where students are still separate and "other") to centre (where students are an integrated and integral part of the Library). This transition in our model for engagement is grounded in the inclusive and inspiring learning communities imagined by thinkers such as bell hooks. The work undertaken highlights the powerful development opportunities for both the UMLST and the Library as a result of this model of engagement. Finally, we assert that this change, from touchstone "check-in" to integrated contributors is a viable path for academic libraries seeking to extend their own work into the student lifecycle. 


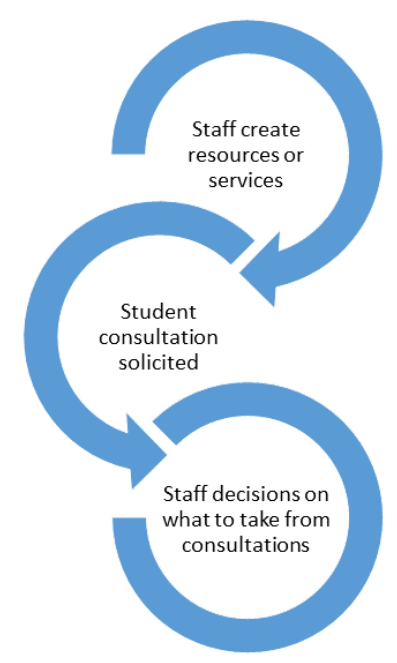

Figure 1--Student Consultation model

Student engagement in the consultant model (see figure 1) can be a powerful way to reflect on services or suggest new avenues. This model places the students at the heart of the process, and allows their experiences and opinions to be incorporated in wider work. Students are being recognised as experts in the space or experience and able to give insightful and valuable input, far beyond what might be found in a survey or one-off evaluation. Most significantly, students who engage with the library can become advocates for those activities where they feel they have contributed.

However, it still separates students out as stakeholders/others, as a community the library must seek out, instead of one based on a reciprocal relationship. It puts the onus on the staff creating the service or resource to prioritise and select the elements of the consultation that "fit" the final result. In addition, because students are often brought in for specific and limited time-periods, their suggestions often lack understanding of the broader drivers for the service or resource, further hampering their ability to contribute meaningfully or in a way that is more innovative than reactionary. Although this model is useful, this is a one-way relationship, with the students "giving" ideas or opinions for 
the staff to receive and, later, assess and prioritise. While there are many circumstances where excellent and student-centred results can be achieved it does not create:

"...a collaborative and reciprocal process through which all participants have the opportunity to contribute equally although not necessarily in the same ways to curricular or pedagogical conceptualisation, decision making, implementation, investigation or analysis" (Cook-Sather, Bovill and Felten, 2014).

Also, the consultation model does not necessarily add significantly to a student's sense of belonging to the library community. Because libraries often act as de-facto centres of learning at universities, and are often the physical centres of the campus, the opportunity to draw students in as true partners, part of a reciprocal and developmental relationship on both sides, is key to the future of academic libraries (Mercer-Mapstone et al., 2017). This sort of work can broaden the cohort engaging with the library from those who may more usually be called on as consultants to groups that more typically find themselves underrepresented. In effect, going beyond the model of "consultant" into a "partnership" model allows libraries to broaden the group it interacts with, gathering more insight and sharing the potential of its services across a wider cohort.

\section{Institutional Context}

The University of Manchester is one of the largest single-site universities in the UK. With nearly 40,000 students, it delivers a broad and varied range of degree programmes and its student body reflects the diversity of its offering. The University of Manchester Library is one of five National Research Libraries, home to world-renowned Special Collections and leads on developing vital new services in both research and teaching and learning. Recently, the Library has been recognised for its outstanding teaching and learning support with several Blackboard awards and a National Teaching Fellowship. 
In particular, the University of Manchester Library has been a leader in student support with its multi-award-winning skills support service, My Learning Essentials (MLE) and student engagement, with the UMLST. MLE is a blended-learning skills support offer, with online and face to face learning resources present in every school and faculty at the University and its open and Creative-Commons licensed materials in use in over 170 countries worldwide. The launch of MLE coincided with the opening of the Alan Gilbert Learning Commons (AGLC), a "bookless" library that sought to put students and their learning at the heart of the building and give students the agency to choose how they needed to work and study.

\section{My Learning Essentials}

"No pedagogy which is truly liberating can remain distant from the oppressed by treating them as unfortunates and by presenting for their emulation models from among the oppressors. The oppressed must be their own example in the struggle for their redemption" (Freire \& trans. Ramos, 2005, p. 54).

With its basis in constructivist theory and emphasis on interaction and facilitative learning and teaching, My Learning Essentials has always had strong links to the students that access its resources and attend its workshops (Blake and Illingworth, 2015). There are three primary ways that students, and others, access this support. First, there are over twenty online resources, available at any time and applicable across all degree programmes. These resources are freely available on the Library website and are often embedded within the virtual learning environment. For face to face support, students can access self-selecting centralised workshops that see participants across year groups and degree programmes working collaboratively to improve their skills and understanding. The third option for accessing My Learning Essentials is via face to face sessions embedded within a course or module. In this case, the Library team (including 
members of UMLST) work with specific academics to tailor the support to a specific module or assessment. MLE has an explicit goal to create welcoming and inclusive learning communities, and to use the power of the library as a central hub to allow students to explore areas where they may feel unsuccessful, unsure or unwelcome. We seek to do this with the way we design our sessions, how we present our materials and with the transparent involvement of co-creators that represent the breadth of the student body; our UMLST.

\section{The University of Manchester Library Student Team}

Originally envisioned as "student rovers", the first iteration of the UMLST was focused on the building itself, employing current students to build a bridge from the work of the academic library to the reality of student life and study. These "rovers" were meant to support My Learning Essentials, collect usage statistics for different aspects of the AGLC, help promote Library services and act as points of contact for students. They are funded from a designated budget set aside for the Student Team and are managed within the Teaching, Learning and Students division, where they have strong links to the services that support students from widening participation through to work with post-graduates. This means that they are naturally a part of all these services and live on the front-lines with the rest of Library staff. Whilst there was some initial resistance, Library staff now see the UMLST as invaluable, both for their connections to the students, PGTs, and PGRs at the University of Manchester and because of their enthusiasm and inspiring ideas.

The high impact work of the UMLST is also a result of its structure, which allows us to recruit from across the University of Manchester and from a wide variety of skill-sets. Initially recruited from a pool of University Student Ambassadors (casual 
workers for the central University recruitment initiatives), the UMLST began with six students each working eight hours a week, normally spread across two shifts of four hours. Now over a dozen on the team, UMLST students are deliberately recruited from the breadth of the faculties across the University of Manchester and represent undergraduates, post-graduates and Postgraduate Researchers. In addition, they are exceptionally diverse in background and bring a number of extremely valuable skills to the Library including coding, second and third languages, experience teaching and tutoring and more.

These skills allow the Student Team to match the demands of the Library services and enhance our offer. They are able to select work to do during their shifts, and the flexibility of these shifts allows students to work around their course schedules and academic and personal demands, opening up the UMLST to students who might not be able to engage otherwise, such as mature students or those commuting to their degree. Team members are allowed to set their own shifts within a set of criteria and are encouraged to bring new and different ideas to the attention of those leading Library services. This has seen work being done in our widening participation service to move the current programme to a more effective and inclusive one, with our DigiLab programme to bring code clubs and technological advances and research to the wider university community and a number of presentations at conferences including the Researching, Advancing and Inspiring Student Engagement (RAISE) conference and the information literacy conference, LILAC. Most of these initiatives are funded out of the existing budget for the services, with some funding coming from external awards. Further detail on the activities of the UMLST can be found in Table 1 in the appendix.

Because we had a dedicated budget for the UMLST, we were able to employ the 
students for a much longer period, far beyond what would have been the case if funding had been tied to individual initiatives. These students were here for the long-haul and without a specific deadline for the end of their contributions. Students remain with us for as long as they are "current" students of the University, with some staying with us from first year undergraduate through to a postgraduate degree, and a few staying on and joining the University as full-time members of staff. This has meant that our engagement with them is deeper and more complex than with a group of students brought in for only one project and that they become invested in the services we cocreate.

The UMLST evolved as they became further embedded in our services. Much of the work done by the first group hired can be termed "typical" of customer service facing staff, with a heavy emphasis on gathering statistics and answering queries. They acted as a bridge between the work of the Library and the work done by students--allowing the Library to promote their services and ask students for their feedback. This is a typical model for student engagement with the expertise of a small group being used to connect services to the large student body or seeking to ask student opinion on already established resources or policies (Walton, 2012).

When first launched, the UMLST involvement in MLE was limited to face to face work, with some quality assurance work for online materials. This student voice work was valuable but continued to place the students in the role of "other" who could only join in when asked and whose contribution was limited to reaction to already created materials or plans (Parsell, 2000; Seale, 2009). Even with these limitations, the UMLST immediately became essential to the feel of MLE, warmly welcoming students into workshops and supporting their work in the sessions, triaging queries at drop-ins 
and ensuring that the online resources were accessible and applicable to the students using them. Although it worked well, and MLE won several awards during this early stage, it quickly became clear that we were not taking advantage of the full potential of having current students on staff for extended periods of time. As the UMLST became more and more a part of the full scope of My Learning Essentials, and the wider Library, their role began to shift. The very nature of their roles, because they were modeled on "staff" roles rather than student consultations, meant that they gradually took on more responsibilities and contributed to more services across the Library. Over time we observed the students developing their individual skill set as they moved into activities that Seale defines as 'teacher centric': seeing, asking, hearing and reflecting (Seale, 2009). The UMLST showed the students engaging with the service that the Library was both for them and led by them, underlining the inclusive nature of the pedagogy and increasing student engagement with My Learning Essentials, presenting students with opportunities to lead their peers and input into the future of the Library's services and skills support. The more we worked with UMLST, the more our model evolved from an integration of the student voice (consultancy) to one of partnership where student contributions are given equal weight, worth, consideration and value.

\section{Student-team as co-creators of resources and teaching}

The pedagogy around co-creation, constructivist teaching and learning and learning communities is familiar and reasonably common (Tinto, 2003; Thomas, 2012; Ryan and Tilbury, 2013; Cook-Sather, Bovill and Felten, 2014). However, there is a significant difference between students-as-learners co-creating the learning community and students-as-facilitators or teachers co-creating learning materials and resources on a service-wide level. In effect, we went from the model shown in figure 1, with the 
“expert" bracketing the student contribution, to a new model (figure 2), where students were part of every stage, and able to bring their understanding of the community and its needs to the whole of the work.

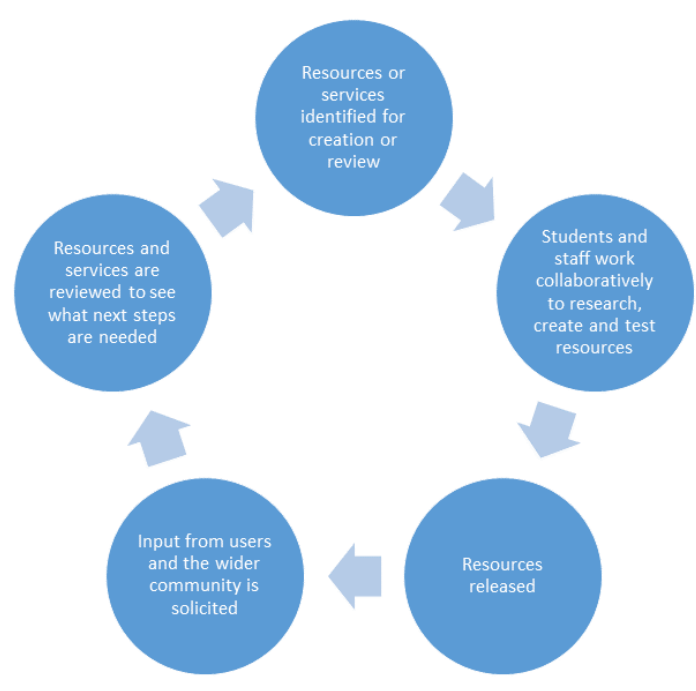

Figure 2--students as partners and community

Changing the model from consultants to co-creators and true partners was not instantaneous. Because this model was less common at the University (in comparison to the idea of student consultants, which is widely used), the idea that current students could make more substantive contributions and should have more control over the final resource was met with some uncertainty and concern. The more standard "banking" model of learning places students in the place of the "receiver", and even learner-led pedagogy still focuses on what happened in the classroom. As a result, any sort of equal contribution on the part of the students to the resources and direction of the service as a whole challenged the common practice (Freire, 1988; Iversen et al., 2015). Although the pedagogical foundation of MLE was focused around co-creation and facilitation, this methodology was not completely embedded into the work behind the scenes. Those working to create the services and its materials were used to thinking of students as 
equals in the classroom, but there was understandable nervousness felt around letting go of the "expert-led" model of creation. The reality was that the UMLST was still being treated as a checkpoint in the process, instead of a cohort that could be equal contributors to development.

It became clear that we needed to expand our concept of where and how "students" could engage with our services. It was of course imperative to ensure they engage with them at point of need, they were there to support after all. It was equally important they engage with the active creation of our services as well. This links directly to the issues mentioned by bell hooks around collaborative work, where the classroom must be seen as a communal place, where all voices are welcome, to create truly effective learning communities (hooks, 1994). We needed to expand our idea of where the "learning" was taking place. Effectively, we were expanding our classroom to encompass the Library itself; suddenly we were all, students and staff, learners on a journey. By joining up with the Library as a whole from the very beginning, the UMLST became more than the link to the student body for the service; they became a source of power to drive the service forward as well. However, to take full advantage of the possible innovation and insight found in UMLST, the models we used to work together needed to shift and some of the more traditional viewpoints in the Library needed to be challenged.

As this work went on, the UMLST was growing, employing over a dozen students in 2016 and nearly twenty by 2019. The UMLST now represents each faculty and undergraduate and post-graduate research and taught students. It is also more diverse than much of the Library, with representation from black and minority ethnic students representative of the breadth of the student body, in comparison to the predominantly white staff found in the rest of the Library. 


\section{The evolution of a new model of student co-creation}

Because of all of the underlying work that needed to be done, this new model of engagement started small. While they still did essential work in welcoming students and quality-assuring resources, the UMLST began to expand into creating their own educational resources. At first, these focused on work that was supplementary to the core offer including blog posts and podcasts. The podcasts allowed the UMLST to reach out directly to those who needed the service and present their own ideas. They were speaking from a place of expertise and leading from conception through to execution of the support. They were, in fact, engaging with their own community, the students, via the Library's services. The success of this work was reflected in their continued embedding into the face to face self-selecting sessions. They continued to work as greeters and support during the sessions but also began to steadily increase the amount of original, non-consultative work they put into resources and teaching sessions. Many of them began to deliver teaching as well. These slow but steady steps allowed others at the Library to support the status of the UMLST as equal members of staff, and their success proved, again and again, that they could deliver a level of expertise on par with more traditional roles.

As their contributions to original materials and resources grew, their freedom to lead on true peer-led learning increased. Working in partnership with others on the My Learning Essentials team, the UMLST began to create and deliver bespoke sessions on exam support, one to one peer support for drop ins and evolve from "support" for face to face sessions to active facilitators (Grayson, Blake, Stock, 2018). Students could see their peers, and thus themselves, exploring and developing powerful strategies to help their own academic skills and mental wellbeing. Longer-term staff at the Library could 
see the success of the UMLST-created materials and their connections to the students and the perspectives around "where" student engagement should be sought began to shift. When "we" the Library used Snapchat or led on a University Instagram campaign, we were not attempting to interrupt a conversation held elsewhere. We were already there, part of the discussion, a fellow of the community. With our transformed model, students were no longer something to reach "out" to, but a part of our community to begin with.

The evolution of the work of the UMLST on My Learning Essentials meant that their contributions moved from solely face to face to contributing to the creation of resources and workshops. They began publishing on their work and highlighting the work of the team at conferences and other events (Grayson, Blake and Stock, 2018). As all of this was going on, they began to contribute at a high level to cross-University projects. Other services across the University recognised the success the Library was having at engaging students both as participants and as contributors to their services. The Library's ability to hear and rapidly respond to student needs meant that, for example, changes to individual modules' assessments could result in a corresponding shift in Library support. It also meant that the Library could effectively work with other centralised services to support their efforts to reach students, with the student wellbeing champions reflecting the feel and model of the UMLST.

The UMLST continues to lead on exam support. The Library's exam-focused support, Exam Extra, takes place just before and throughout both winter and spring exam periods. Exam Extra encompasses extra spaces for revision, face to face drop-in support and a focused set of face to face sessions to enable students to revise effectively. Though it had always been reasonably popular, it was the UMLST's work to completely revise and refocus the materials used in the face to face drop ins that 
allowed it to properly support students during revision. The presence of UMLST members on the exam stands also led to greater engagement from students, as UMLST both felt more comfortable welcoming students to the materials and presented a "friendly" face for students to engage with. They had moved from consultants on the materials to leaders on the creation, and once again the Library was engaging with the community around them, instead of reaching out via a surrogate method to what was outside.

\section{Conclusion}

The UMLST is now viewed within the Library as integral to the success of its services. They branched out to work on My Research Essentials, the Library's support service for post-graduate researchers, new academics and others needing support for their research. They regularly step in to deliver face to face sessions for both services and many of them have now achieved Associate Fellowship of the Higher Education Academy. The UMLST was highlighted as an example of best practice in the higher education sector in the University's TEF application and UMLST members regularly spend the entirety of their career at Manchester as part of the team, demonstrating the level of engagement they felt with the work they were doing and simultaneously acting as examples for how much the student community is valued by its Library.

As the Library's success at engaging students became more and more evident, other parts of the University began to model their own "student teams" on what was happening in the Library. Some of these teams began with one intern on a fixed term contract, some were larger and more explicitly modelled on the work being done at the Library. All of the teams reached out for advice and support from the Library on successfully engaging students behind the scenes as well as during their studies. For the Library, this meant internal and sector-wide recognition not just of our resources and 
services but of our ability to connect our services and resources with those who needed them. The AGLC had always been viewed as a central hub for skills, but the work of the UMLST had made the entire Library, and all its resources and staff, much more than a hub. We were looked at as inclusive and innovative practitioners, who knew and could articulate what students needed and how the wider institution could build a reciprocal and vibrant community that naturally brought students and staff together.

Going forward, the UMLST will continue to be a core part of our service development and delivery. Their expertise and enthusiasm are now contributing to taught courses (in the form of supplementary podcasts), and we envisage similar engagement with our widening participation service. They will spark our own ideas and inspire proactive innovation. They will enable us to reach out to the schools and schoolaged students who might not see academic libraries as a place for them. And they will keep our students' voices, blazing ideas and matchless enthusiasm at the centre of all we do.

Our work around student engagement showcases a strength of the Library that might be overlooked; its ability to act as a connection between what is needed, for learning, for research, and what is available. The ability to engage with students in complex and long-term partnerships has strengthened the Library's belief in what is possible, and serves as inspiration to the rest of our institution (Healey, M; Healey, 2019). Because of this strength, and in recognition of how far ahead the Library is in truly engaging students in creating resources and applying them to their learning, the Library was invited to contribute to a cross-university group that looked at potential new approaches for curriculum development and assessment and is now often represented in high level conversations around teaching, learning and students that go far beyond what might be deemed typical for a library. 
The UMLST's results speak for themselves, but it is the changes in the Library, and our newfound ability to harness the expertise and engagement of students within our services instead of just with them, that is their lasting legacy. The UMLST have moved themselves, and thus the Library's perception of students more generally, from a cohort that needed consulting or "serving" to one that could be depended on to create and collaborate, to strengthen the Library's services, student engagement and understanding. They have succeeded in expanding the "learning community" spoken of by hooks, Freire and others to encompass the whole of the Library, teaching the staff as much as supporting the students. Because of this, because our model of engagement now has equal and internal aspects, because our students engage to create as well as to utilise, the Library is now a true centralised hub for understanding. The students are no longer "other", and we no longer require a bridge to reach them. Instead, we are one community, using our combined strengths and insights to drive forward the work we do and the opportunities we create.

\section{References}

AdvanceHE (2019) Student engagement through partnership in higher education | Advance HE, Student Engagement. Available at: https://www.advancehe.ac.uk/guidance/teaching-and-learning/student-engagement-through-partnership (Accessed: 16 January 2020).

Blake, J. and Illingworth, S. (2015) 'Interactive and Interdisciplinary Student Work: A Facilitative Methodology to Encourage Lifelong Learning', Widening Participation and Lifelong Learning, 17(2), pp. 108-118. doi: 10.5456/wpll.17.2si.107.

Cook-Sather, A., Bovill, C. and Felten, P. (2014) Engaging Students as Partners in Learning and Teaching. Jossey Bass.

Cook-Sather, A. and Felten, P. (2017) 'Where student engagement meets faculty 
development: How student-faculty pedagogical partnership fosters a sense of belonging', Student Engagement in Higher Education Journal.

Freire, P. (1988) 'Banking v Problem Solving Models of Education', Padagogy of the Oppressed, pp. 52-67. Available at: http://www.nottingham.ac.uk/ ttzelrn/contextse/unit1/documents/Freire_1990_000.pdf.

Freire, P. and trans. Ramos, M. (2005) 'Pedagogy of the Oprressed: 30th Anniversary Edition', Pedagogy of the Oppressed. doi: 10.1016/B978-1-4160-4389-8.50161-8.

Grayson, N. J., Blake, J. and Stock, M. (2018) 'The Co-creation of Exam Support: Students as partners in the research, planning, design and quality assurance of learning resources.', The Journal of Educational Innovation, Partnership and Change, 4(1). doi: 10.21100/jeipc.v4i1.767.

Healey, M; Healey, R. (2019) Students as partners guide: student engagement through partnership. Available at: https://www.advance-he.ac.uk/knowledge-hub/studentspartners-guide-student-engagement-through-partnership.

hooks, bell (1994) Teaching to transgress : education as the practice of freedom. Routledge.

Iversen, A.-M. et al. (2015) 'Learning, Leading, and Letting Go of Control', SAGE Open, 5(4), p. 215824401560842 . doi: 10.1177/2158244015608423.

Mercer-Mapstone, L. et al. (2017) 'A Systematic Literature Review of Students as Partners in Higher Education', International Journal for Students as Partners. McMaster University Library Press, 1(1). doi: 10.15173/ijsap.v1i1.3119.

Murphy, J. A. F. (2017) 'A New Student Learning Focus for the Academic Library: From Geographical Proximity of the Learning Commons to Organizational Proximity within the Library', Journal of Library Administration. Routledge, 57(7), pp. 742-757. doi: 10.1080/01930826.2017.1360686.

National Union of Students (2014) 'Building a Framework for Partnership With Students: Student Charters Three Years On.', pp. 1-11. Available at: https://www.nusconnect.org.uk/resources/building-a-framework-for-partnership-withstudents (Accessed: 16 January 2020).

Parsell, G. (2000) 'Asking questions - improving teaching', Medical Education, 34(8), 
pp. 592-593. doi: 10.1046/j.1365-2923.2000.00750.x.

Ramsden, P. (2002) Learning to Teach in Higher Education, Learning to Teach in Higher Education. Routledge. doi: 10.4324/9780203413937.

Ryan, A. and Tilbury, D. (2013) Flexible Pedagogies: new pedagogical ideas Flexible Pedagogies: preparing for the future.

Schlak, T. (2018) 'Academic Libraries and Engagement: A Critical Contextualization of the Library Discourse on Engagement', Journal of Academic Librarianship. Elsevier Ltd, 44(1), pp. 133-139. doi: 10.1016/j.acalib.2017.09.005.

Seale, J. (2009) 'Doing student voice work in higher education: an exploration of the value of participatory methods', British Educational Research Journal, 36(6), pp. 9951015. doi: 10.1080/01411920903342038.

Thomas, L. (2012) Building student engagement and belonging in Higher Education at a time of change: final report from the What Works? Student Retention \& Success programme Final Report.

Tinto, V. (2003) 'Learning better together: The impact of learning communities on student success', Higher Education monograph series, 1, pp. 1-8. Available at: http://citeseerx.ist.psu.edu/viewdoc/summary?doi=10.1.1.576.28 (Accessed: 17 April 2020).

Walton, G. (2012) 'Customers, Stakeholders, Patrons, Users, Clients, Members, or Readers? What Do We Call People Using our Services?', New Review of Academic Librarianship, pp. 111-113. doi: 10.1080/13614533.2012.707799. 